\title{
Expression of estrogen receptors in the pelvic floor of pre- and post-menopausal women presenting pelvic organ prolapse
}

\author{
Monika Zbucka-Kretowska ${ }^{1}$, Naama Marcus-Braun ${ }^{2}$, Cyril Eboue ${ }^{2}$, \\ Geneviève Abeguile ${ }^{3}$, Slawomir Wolczynski ${ }^{1}$, Marie Laure Kottler ${ }^{3}$, \\ Peter Von Theobald ${ }^{2}$
}

\author{
${ }^{1}$ Department of Reproduction and Gynecological Endocrinology, \\ Medical University of Bialystok, Poland \\ ${ }^{2}$ Department of Gynecology Obstetrics and Reproductive Medicine, \\ University Hospital of Caen, France \\ ${ }^{3}$ Department of Reproduction and Genetics, University Hospital of Caen, France
}

\begin{abstract}
The precise role of estrogen in the pathogenesis of pelvic organ prolapse (POP) is still unclear, while the results concerning the effect of selective estrogen receptor modulators on pelvic organ prolapse are contradictory. Our aim was to test whether alteration in the expression of estrogen receptors in the pelvic floor of preand post-menopausal women is related to genital prolapse status. The mRNA levels of ER $\alpha$ and ER $\beta$ in 60 biopsy specimens were measured. Significantly higher expression of $\mathrm{ER} \alpha$ and higher $\mathrm{ER} \alpha / \mathrm{ER} \beta$ ratio were demonstrated in post-menopausal women compared to pre-menopausal women. Higher expression of ER $\alpha$ and higher $\operatorname{ER} \alpha / \operatorname{ER} \beta$ ratio were detected in all studied groups with POP, thus it did not reach significance in the post-menopausal group. Pre-menopausal and post-menopausal women presenting pelvic organ prolapse had no difference in the ER $\alpha$ expression. Our preliminary study may indicate that pelvic organ prolapse is associated with higher expression of $\mathrm{ER} \alpha / \mathrm{ER} \beta$ in the pelvic floor of both pre- and post-menopausal women; thus not reaching statistical significance in the post-menopausal women was probably due to the group's size. We believe that the inevitable changes in the estrogen receptor expression over women's different lifetimes may affect the risk of genital prolapse progression, and might contribute to the further search for appropriate selective estrogen receptor modulators as a treatment for women with pelvic organ prolapse. (Folia Histochemica et Cytobiologica 2011; Vol. 49, No. 3, pp. 521-527)
\end{abstract}

Key words: estrogen receptor, menopause, pelvic organ prolapse, RT-PCR, SERMs

\section{Introduction}

Pelvic organ prolapse (POP) can be observed in women whose tissues and muscles holding their pelvic organs have stretched or weakened. Epidemio-

\footnotetext{
Correspondence address: M. Zbucka-Kretowska, Department of Reproduction and Gynecological Endocrinology, Medical University of Bialystok, Sklodowskiej Str. 24A, 15-276 Poland; tel.: (+ 48 85) 74683 43, fax: (+ 48 85) 74688 18; e-mail: monikazbucka@wp.pl
}

logic data suggests that a woman's lifetime risk for undergoing prolapse reconstructive surgery is approximately $11 \%$ by the age of 80 [1]. In addition, $30 \%$ of women will undergo multiple procedures for POP repair [1,2].

Observational and clinical studies have demonstrated that pelvic organ prolapse is diagnosed most frequently in post-menopausal women and there is significant evidence that the condition is mainly related to pregnancy and labor [3]. Nevertheless, POP has also been recorded in virginal and nulliparous women, and can be caused by other factors which 
might increase abdominal pressure such as: obesity, chronic cough and constipation as well as prior pelvic surgery and connective tissue disorders $[4,5]$.

The current knowledge of the pathophysiology of POP is still scanty. Since pelvic organ prolapse can also appear in pre-menopausal and nulliparous women, one could suggest the role of the quality of connective tissue of the pelvic supportive structures in the development of POP. On the other hand, there is strong evidence that hypoestrogenic state may contribute to the development of prolapse, since the prevalence of POP is mainly in the post-menopausal period [4]. The precise role of estrogens in the pathogenesis of the pelvic organ prolapse is still unknown. Several publications which have studied the effect of estrogen and Selective Estrogen Receptor Modulators (SERMs) on POP, have been inconsistent. In some studies, raloxifene and tamoxifen appeared to worsen the prolapse when compared with conjugated equine estrogen and placebo [6,7]. In other studies, the protective influence of raloxifene on the development of POP after nine months of therapy and a $50 \%$ reduction of the surgical intervention risk in post-menopausal women have been reported [8]. Furthermore, SERMs such as levormeloxifene and idoxifene have been found to increase the risk of pelvic organ prolapse and POP was reported as an adverse event associated with both drugs $[9,10]$.

The aim of our study was to test whether alteration in the expression of estrogen receptors in the pelvic floor of pre-menopausal and post-menopausal women is related to pelvic organ prolapse status, and whether it can shed light on the contradictory results obtained from different studies with SERMs. We quantified the mRNA levels of both forms of estrogen receptors, $\alpha$ and $\beta$ ( $\operatorname{ER} \alpha$ and $\operatorname{ER} \beta)$, in the vesico-vaginal and recto-vaginal walls of the pelvic floor in relation to menopausal status and the presence of POP.

\section{Material and methods}

The regional ethical committee (Comité de Protection des Personnes Ile de France X) approved the study. Sixty biopsy specimens from pelvic floor tissues were obtained from 30 patients categorized into four groups. Group 1: pre-menopausal women with POP $(n=4$, mean age $40.7 \pm 6.0$ years), group 2: pre-menopausal women without POP $(\mathrm{n}=5$, mean age $47.3 \pm 3.0$ years), group 3: post-menopausal women with POP $(n=12$, mean age $62.9 \pm 8.2$ years $)$ and group 4: post-menopausal women without POP $(n=9$, mean age $65.0 \pm 12.2$ years). The quantification of the mRNA levels of estrogen receptors (ERs) was carried out in samples of connective tissue obtained at the upper third of the vesicovaginal and recto-vaginal walls from patients undergoing hysterectomy or surgery for prolapse and were examined also by pathologists. Samples were deep frozen in liquid nitrogen and stored until RNA extraction.

The RNA was isolated according to Chomczynski's protocol [11]. $\mathrm{ER} \alpha$ and $\mathrm{ER} \beta$ mRNAs were measured by quantitative assays based on Reverse Transcription (RT) of the mRNA and real-time Polymerase Chain Reaction (PCR) amplification of the cDNA. Using the RT-PCR technique, mRNA of both ERs was successfully detected in the vesicovaginal fascia tissue and recto-vaginal fascia tissue.

Preparation of real-time PCR mix. All of the PCR reactions were performed with an ABI Prism 7700 Sequence Detection System (Applied Biosystems, Los Angeles, CA, USA). PCR was performed using the Taqman Reagents kit. The amplification reactions were performed in a $30-\mu \mathrm{L}$ final volume containing $5 \mu \mathrm{l}$ cDNA, $15 \mu \mathrm{l}$ Taqman Probe Biorad. Final ER $\alpha, \operatorname{ER} \beta$, Glyceraldehyde 3-phosphate dehydrogenase (GAPDH) forward and reverse primer concentrations are listed in Table 1.

Real-time RT-PCR and temperature profiles. The real-time RT-PCR protocol used for quantification of $\mathrm{ER} \alpha, \mathrm{ER} \beta$ was as follows: initial denaturation: $94^{\circ} \mathrm{C}$ for 10 minutes; annealing and elongation: $94^{\circ} \mathrm{C}$ for 60 seconds; $65^{\circ} \mathrm{C}$ for 60 seconds; $72^{\circ} \mathrm{C}$ for 45 seconds; repeated 30 times with additional $10 \mathrm{~min}$ extension for the last cycle.

Relative gene expression quantification. The value of termed cycle threshold $\left(\mathrm{C}_{t}\right)$ was determined by the number of the first cycle at which fluorescence was greater than the set threshold value. The average $C_{t}$ of duplicate samples was calculated. The quantities of the studied ER transcripts were calculated using the standard curves for $\mathrm{ER} \alpha$ or $\mathrm{ER} \beta$ and normalized by the level of GAPDH mRNA and by correction factors: $10^{-2}$ and $10^{-3}$ for the ER $\alpha$ and $\operatorname{ER} \beta$ expressions respectively.

Statistical analysis. Since the expressions of $\operatorname{ER} \alpha$ and $\operatorname{ER} \beta$ were non-normally distributed, the studied variables were expressed as median and 1-3 quartile range. The differences between the groups were compared by Mann-Whitney U test using the Statistica 5.1 program (Statsoft 5.1, Tulsa, OK, USA). The results were considered significant when $\mathrm{p}$ values were lower than 0.05 .

\section{Results}

The expression of both $\operatorname{ER} \alpha$ and $\operatorname{ER} \beta$ were detected in all 60 investigated tissues. The comparison of the ERs expression and the $\mathrm{ER} \alpha / \mathrm{ER} \beta$ ratio in the studied tissues between the groups and with relation to POP status is detailed in Table 2. When we compared the ERs expression between pre-menopausal and post-menopausal patients, there was a significantly 
Table 1. Oligonucleotide primer sequences of estrogen receptors and GAPDH for real-time quantitative RT-PCR

\begin{tabular}{|l|c|c|}
\hline Gene & Sequences $\left(\mathbf{5}^{\prime} \boldsymbol{\rightarrow} \mathbf{3}^{\prime}\right)$ & Final concentration $(\mathbf{p M})$ \\
\hline GAPDH $^{*}$ & F: ATT CCA CCC ATG GCA AAT & 0.33 \\
& R: GGC AGA GAT GAT GAC CCT TT & 0.33 \\
\hline ER $\alpha^{\dagger}$ & F: TGC TTC AGG CTA CCA TTA TGG AGT CTG & 3.75 \\
& R: GTC AGG GAC AAG GCC AGG CTG & 3.75 \\
\hline ER $\beta^{\dagger \dagger}$ & F: TTT AAA AGA AGC ATT CAA GGA CAT AAT G & 3.75 \\
& R: CGG TGA AGG GCG CAC TG & 3.75 \\
\hline
\end{tabular}

F — forward; R — reverse; *GAPDH - glyceraldehyde 3-phosphate dehydrogenase; ${ }^{\dagger} \mathrm{ER} \alpha$ - estrogen receptor $\alpha$; ${ }^{\dagger+} \mathrm{ER} \beta$ - estrogen receptor $\beta$

Table 2. Comparison of the estrogen receptors expression in the vesico-vaginal and recto-vaginal fascia tissues between the studied groups and with relation to POP status

\begin{tabular}{|c|c|c|c|c|c|c|}
\hline & ER $\alpha$ expression & $\mathbf{p}$ & ER $\beta$ expression $*$ & $\mathbf{p}$ & $\mathrm{ER} \alpha / \operatorname{ER} \beta$ ratio & $\mathbf{p}$ \\
\hline $\begin{array}{l}\text { Pre-menopausal with POP } \\
(\mathrm{n}=4, \mathrm{~S}=8)\end{array}$ & $2.4(0.2-4.5)$ & \multirow[t]{2}{*}{0.013} & $0.48(0.4-2.0)$ & \multirow[t]{2}{*}{0.05} & $12.4(5.2-116.3)$ & \multirow[t]{2}{*}{0.087} \\
\hline $\begin{array}{l}\text { Pre-menopausal without POP } \\
(\mathrm{n}=5, \mathrm{~S}=10)\end{array}$ & $0.2(0.1-0.36)$ & & $2.4(1.1-6.1)$ & & $0.77(0.21-2.2)$ & \\
\hline $\begin{array}{l}\text { Post-menopausal with POP } \\
(\mathrm{n}=12, \mathrm{~S}=24)\end{array}$ & $3.4(1.1-5.9)$ & \multirow[t]{2}{*}{$0.69^{*}$} & $1.14(0.06-4.4)$ & \multirow[t]{2}{*}{$0.82^{*}$} & $29.6(9.1-41)$ & \multirow[t]{2}{*}{$0.65^{*}$} \\
\hline $\begin{array}{l}\text { Post-menopausal without POP } \\
(\mathrm{n}=9, \mathrm{~S}=18)\end{array}$ & $2.1(0.8-5.9)$ & & $1.13(0.09-5.6)$ & & $10.8(1.0-62)$ & \\
\hline $\begin{array}{l}\text { All groups with POP } \\
(\mathrm{n}=16, \mathrm{~S}=32)\end{array}$ & $3.3(1.1-4.5)$ & \multirow[t]{2}{*}{0.032} & $1.1(0.5-2.0)$ & \multirow[t]{2}{*}{$0.18^{*}$} & $27.3(9.1-41)$ & \multirow[t]{2}{*}{0.035} \\
\hline $\begin{array}{l}\text { All groups without POP } \\
(\mathrm{n}=14, \mathrm{~S}=28)\end{array}$ & $0.36(0.2-2.9)$ & & $2.2(1.1-5.6)$ & & $2.2(0.8-13.7)$ & \\
\hline $\begin{array}{l}\text { All groups pre-menopausal } \\
(\mathrm{n}=9, \mathrm{~S}=18)\end{array}$ & $0.25(0.2-2.4)$ & \multirow[t]{2}{*}{0.006} & $1.1(0.7-4.9)$ & \multirow[t]{2}{*}{$0.55^{*}$} & $1.92(0.7-12.4)$ & \multirow[t]{2}{*}{0.026} \\
\hline $\begin{array}{l}\text { All groups post-menopausal } \\
(\mathrm{n}=21, \mathrm{~S}=42)\end{array}$ & $3.2(1.0-6.0)$ & & $2.1(0.6-2.7)$ & & $22.1(7.3-46.9)$ & \\
\hline
\end{tabular}

$\mathrm{n}$ - number of patients; $\mathrm{S}$ - number of biopsy specimens; \#calculated using the standard curves for ER $\alpha$ or ER $\beta$ and normalized by the level of GAPDH mRNA and by correction factors: $10^{-2}$ and $10^{-3}$ for the $\operatorname{ER} \alpha$ and $\operatorname{ER} \beta$ expressions respectively ; *non significant

higher expression of $\mathrm{ER} \alpha$ and higher $\mathrm{ER} \alpha / \mathrm{ER} \beta$ ratio in post-menopausal women. Higher expression of $\operatorname{ER} \alpha$ and higher $\operatorname{ER} \alpha / \operatorname{ER} \beta$ ratio were detected in all studied groups with POP, thus it did not reach significance in the post-menopausal group. Pre-menopausal women presenting POP had in addition lower expression of $\operatorname{ER} \beta$ compared to pre-menopausal women without POP. Figures 1-3 demonstrate the ER $\alpha$ and $\mathrm{ER} \beta$ expression in connective tissue of vesico-vaginal and recto-vaginal fascias (median, 1-3 quartile) in pre-menopausal women (Figure 1), in post-menopausal women (Figure 2), and in all studied groups (Figure 3) with versus without POP. The comparison of $\mathrm{ER} \alpha / \mathrm{ER} \beta$ ratio in women with versus without $\mathrm{POP}$ in pre- and post-menopausal women and in all studied groups is presented in Figure 4.

After stratification by POP status, a significant difference in the expression of $\mathrm{ER} \alpha$ between pre-menopausal and post-menopausal patients were still observed in women without prolapse $(\mathrm{p}=0.032)$. In contrast, there were no differences in $\mathrm{ER} \alpha$ expression in pre-menopausal women with POP compared to post-menopausal women with POP; both groups had relatively high levels of ER $\alpha$ mRNA in the studied tissues. The expression of $\operatorname{ER} \beta$ did not differ before and after menopause, when all studied women were analyzed, or after stratification by POP status.

\section{Discussion}

The pathogenesis of POP is multifactorial, although estrogen activity and the quality of connective tissue seem to play crucial roles. The clinical course of patients with symptomatic pelvic organ prolapse clearly suggests that POP development is promoted mostly by a hypoestrogenic environment [5]. Yet, estrogen activity is dependent not only on serum estrogen level, but also on the expression of estrogen receptors. Additionally, there are coregulators and other transcriptional factors that have an effect on the estrogen dependent pathway. 


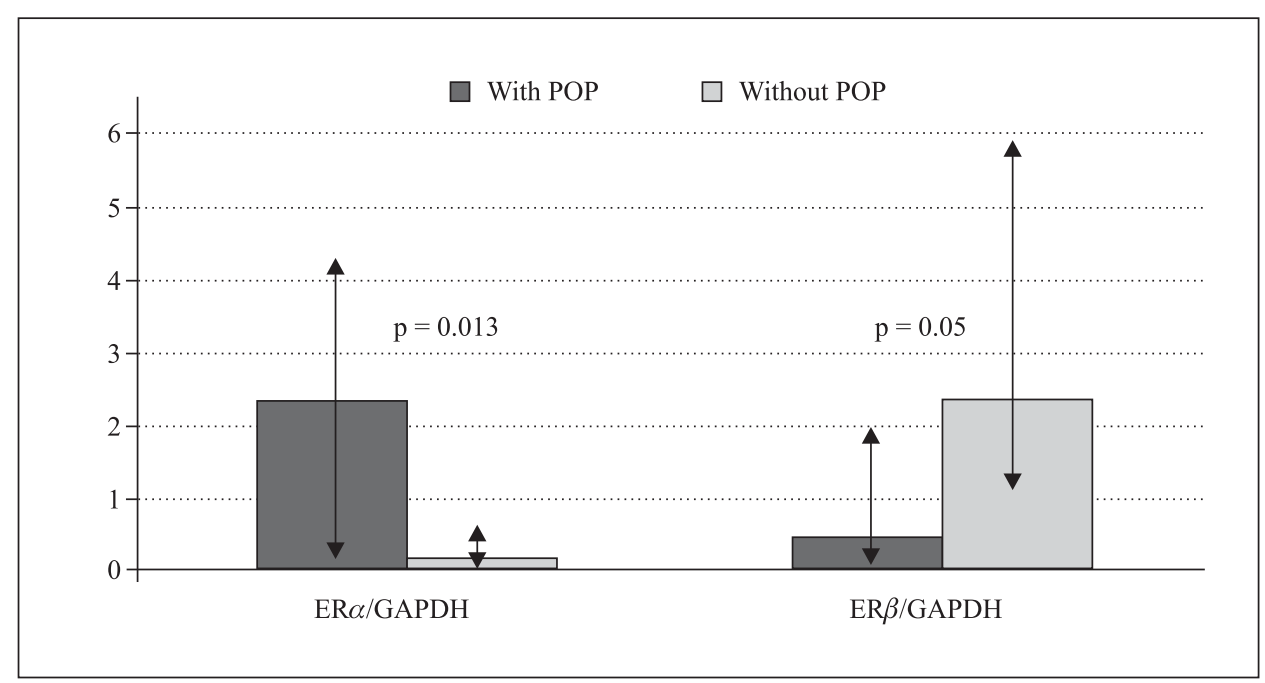

Figure 1. $\mathrm{ER} \alpha$ and $\mathrm{ER} \beta$ expression in connective tissue of vesico-vaginal and recto-vaginal fascias (median, 1-3 quartile) in pre-menopausal women with vs. without POP

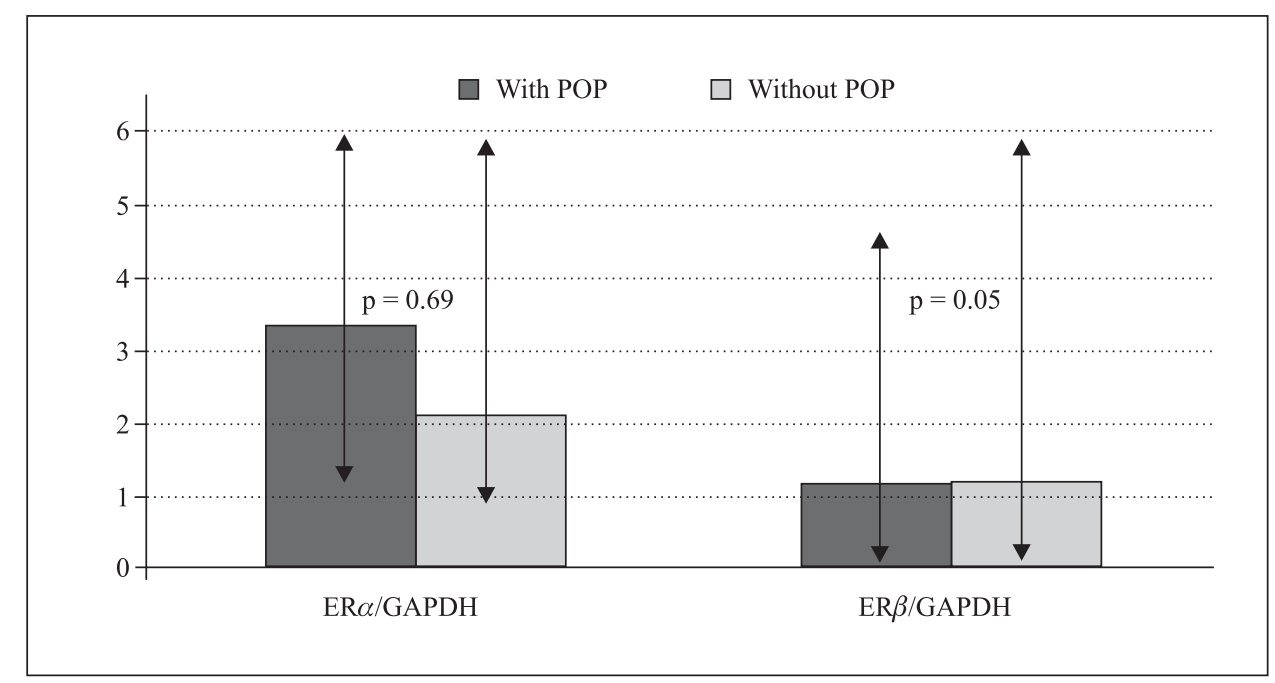

Figure 2. $\mathrm{ER} \alpha$ and $\mathrm{ER} \beta$ expression in connective tissue of vesico-vaginal and recto-vaginal fascias (median, 1-3 quartile) in post-menopausal women with vs. without POP

Numerous experiments have revealed the reciprocal relations between estrogens and connective tissue. Estrogens and ERs regulate most of the genes that encode growth factors engaged in the regulation of the synthesis of extracellular matrix. Alterations in the quantity and quality of collagen, morphology of connective tissue after menopause, and experimental evidence that estrogen modulates the collagen metabolism, strongly indicate the involvement of estrogens in the pathogenesis of pelvic organ prolapse [12]. It is also believed that the appearance of prolapse and mechanical stretch disturb the fibroblast's ability to maintain the cytoskeleton architecture and quality of the extracellular matrix [13]. In addition, estrogen has been shown to decrease tissue-degrad- ing matrix metalloproteinases in fibroblasts derived from pelvic floor connective tissue. Estrogen receptors, $\mathrm{ER} \alpha$ and $\mathrm{ER} \beta$, have been found to be involved in the regulation of estrogen action in human skin fibroblasts [14]. Thus, the effect of estrogens in connective tissue as a target organ depends not only on the exposing levels of estrogen, but also on the intracellular system of estrogen signaling - expression of ERs and their coregulators.

Although it seems reasonable that estrogen improves the mechanical integrity of the pelvic floor tissues, there is insufficient data to support estrogen as a therapy for POP. Reay et al. [15] described decreased thickness and resilience of the uterosacral ligaments removed at hysterectomy from post-menopausal 


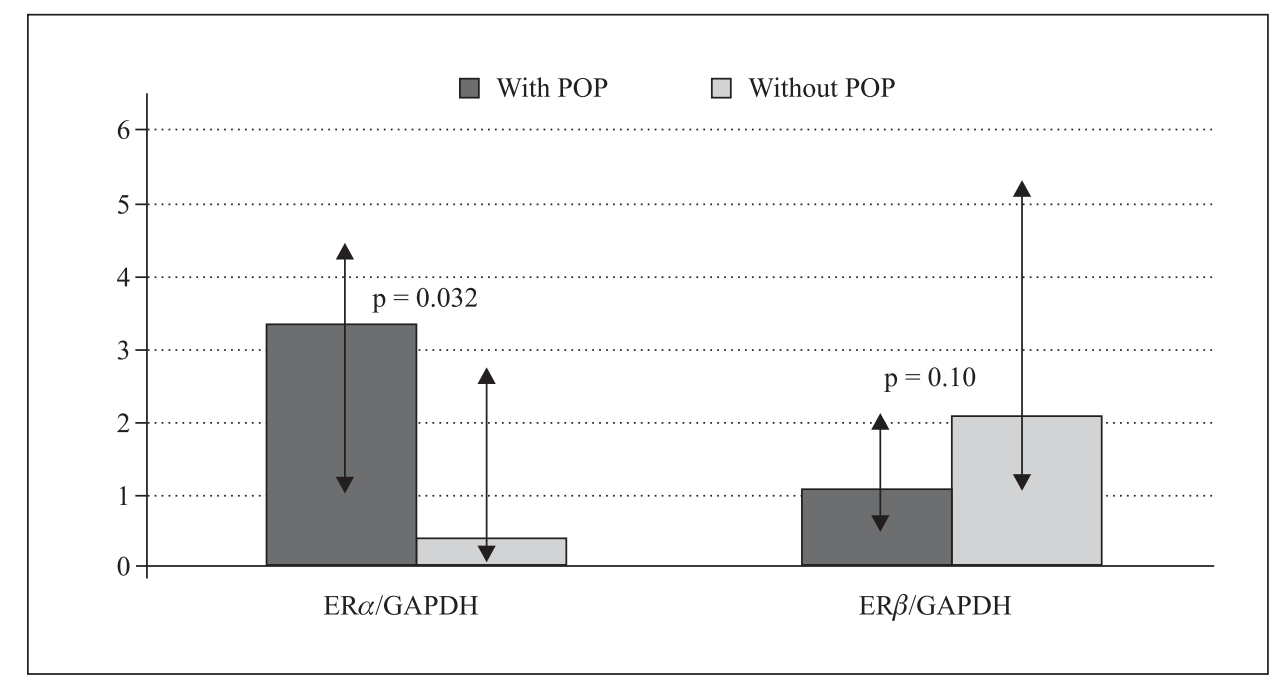

Figure 3. $\operatorname{ER} \alpha$ and $\operatorname{ER} \beta$ expression in connective tissue of vesico-vaginal and recto-vaginal fascias (median, 1-3 quartile) with vs. without POP in all studied groups

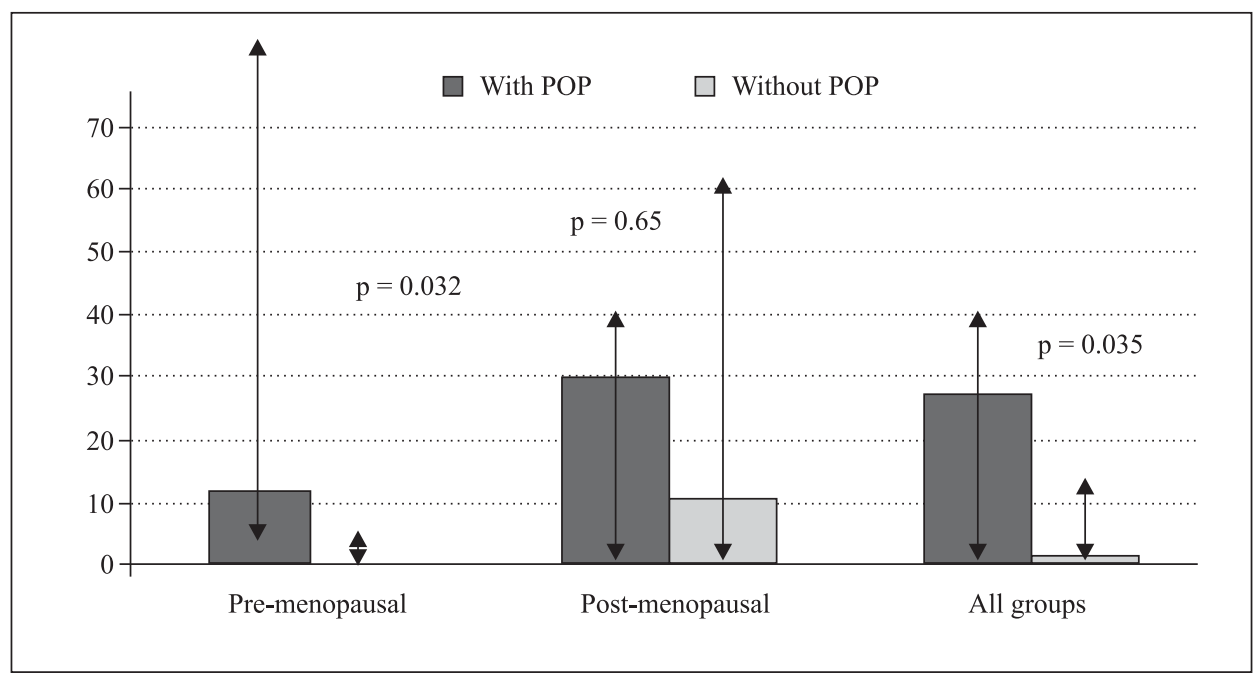

Figure 4. Comparison of $\operatorname{ER} \alpha / \operatorname{ER} \beta$ ratio in women with vs. without POP in pre- and post-menopausal women and in all studied groups

women without hormone therapy when compared with pre-menopausal women. In a rhesus macaque model, it was shown that estrogen therapy increases expression of cystatin $\mathrm{C}$, an inhibitor of collagen proteases $[16,17]$. Vaginal collagen content is determined by the balance between the synthesis and degradation of the collagen. Previous studies have identified ERs in the nuclei of connective tissue and the smooth muscle cells of the bladder trigone, urethra, vaginal mucosa, levator ani stroma and uterosacral ligaments $[18,19]$. The cardinal and uterosacral ligaments play a crucial role in supporting the uterus in its normal position. Serum estrogen levels and ER values have been found to be significantly lower in the uterine ligaments of pre-menopausal women with POP
[20, 21]. However, there was no difference in ER values among post-menopausal women with or without POP when only subtype $\alpha$ of ER was analyzed [20]. Ewies et al. [22] studied the changes in gonadal steroid receptors in the cardinal ligaments of prolapsed uterus. Immunohistochemical analysis of the cardinal ligaments showed 1.5-2.5 times increased expression of ER $\alpha$ in women with POP compared to patients without POP. Additionally, the expression of $\operatorname{ER} \beta$ was twice as high in pre-menopausal women without POP compared to pre-menopausal women with POP, and there was no significant difference between both post-menopausal groups.

In vitro studies show that synthesis of ERs is regulated by SERMs and estradiol. In this setting, it is 
reasonable to anticipate that the expression of ERs varies depending on the status of menopause. Since both estrogen receptors, $\mathrm{ER} \alpha$ and $\mathrm{ER} \beta$, are present in the vesico-vaginal and recto-vaginal fascias, it is possible to modulate the expression of ERs by either the estrogens or the selective estrogen receptor modulators. SERMs such as levormeloxifene and idoxifene, increase the risk of pelvic organ relaxation and POP was reported to the American Food and Drug Administration (FDA) as an adverse event associated with both drugs $[9,10]$. Current analysis, based on data obtained from post-menopausal women treated with raloxifene, demonstrates that raloxifene was associated with a $50 \%$ reduction in the risk of surgery for pelvic floor relaxation in women treated for up to three years [8]. In another analysis, raloxifene was not found to have contributed to pelvic floor relaxation [23]. This data raises the interesting hypothesis that raloxifene may actually contribute to a reduction in the incidence of pelvic floor relaxation, which could be a reflection of estrogen agonist activities on the tissues of the pelvic floor $[8,24]$. The mechanism by which raloxifene might affect pelvic floor relaxation unfortunately is still unclear. The presence of ERs in connective tissues makes the pelvic floor a target for estrogens and SERMs. The remodeling of the pelvic connective tissue is likely to be concerned with aging and menopause. Collagen metabolism associated with the menopause has been observed in bones and skin $[25,26]$. Since abnormal collagen metabolism has been observed in the vaginal tissues of women with genitourinary prolapse, the agents that positively affect collagen turnover may restore pelvic tone and reduce the incidence of pelvic floor relaxation. Although no data yet supports a remodeling effect of raloxifene in pelvic floor tissues, it is well known that raloxifene decreases collagen turnover in the skeleton, an effect that may contribute in part to the $30-50 \%$ reduction in risk for vertebral fracture in post-menopausal osteoporotic women on raloxifene therapy $[27,28]$.

Our results demonstrated higher expression of $\mathrm{ER} \alpha$ and higher $\mathrm{ER} \alpha / \mathrm{ER} \beta$ ratio in post-menopausal women compared to pre-menopausal women and in all groups presenting POP. The results did not achieve statistical significance for the post-menopausal women presenting POP and it could be explained by the higher expression of $\mathrm{ER} \alpha$ and $\mathrm{ER} \alpha / \mathrm{ER} \beta$ ratio in all post-menopausal women and groups' size. The expression of $\operatorname{ER} \beta$ was statistically lower in pre-menopausal women with POP compared to pre-menopausal women without POP and there was no difference between the $\operatorname{ER} \beta$ expressions in post-menopausal women with regards to POP status. The results in the present study, although preliminary, demonstrate different expression of ERs concentration in pre-meno- pausal and post-menopausal women and an alteration in ERs expression with regards to POP status. It is clear that higher $\mathrm{ER} \alpha / \mathrm{ER} \beta$ ratio is related to POP and it is more pronounced in the pre-menopausal group. Therefore, it makes us wonder if the observed quantitative change could participate in the pathogenesis of the development of POP.

The interpretation of our results meets several difficulties. Basically, it is well known that the processes of transcription and translation are not equally efficient. Furthermore, the stability of mRNAs and proteins is different. Hence, it is obvious that mRNA levels cannot precisely parallel the protein expression and reflect actual receptor status. On the other hand, the evaluation of $\operatorname{ER} \alpha$ and $\operatorname{ER} \beta$ mRNA expression levels enables the analysis of factors that were presumably implicated in the regulation of gene expression. Several methodological shortcomings in this study must be recognized. The lack of baseline data around the obstetric history of patients and other clinical risk factors for POP prevented us from clinical comparison between the groups. An additional weakness of this analysis concerns the number of patients recruited for this study, which is rather small. However, two biopsy specimens were obtained from each patient and the results were statistically significant. We believe that this preliminary basic science work can contribute to continuous research and further understanding of the pathophysiology of POP. Finding the role of estrogen in the progression of pelvic organ prolapse is a promising field, since it might be the key for future therapy.

\section{Conclusions}

Higher $\operatorname{ER} \alpha / \operatorname{ER} \beta$ ratio was found to be related to pelvic organ prolapse status in pre-menopausal and in post-menopausal women, although it was more pronounced in the pre-menopausal group presenting POP. Larger studies are required in order to strengthen our results.

Taking all the data into consideration, we cannot state whether the alteration in the expression of ERs is the cause or the result of the pelvic organ prolapse. The effects of treatment using raloxifene on POP are still not consistent, and further investigations are needed in order to show an exact mechanism with protective effect on the pelvic floor. Since there are many local factors responsible for the transmission of estrogen signals, individual expression of ERs in the pelvic floor probably influences the results of treatment with SERMs. Nowadays, we believe that the challenge is to discover a SERM which would have a contraceptive effect, would decrease the risk of breast cancer and finally would decrease the risk of pelvic organ prolapse. 


\section{References}

1. Olsen AL, Smith VJ, Bergstrom JO, Colling JC, Clark AL. Epidemiology of surgically managed pelvic organ prolapse and urinary incontinence. Obstet Gynecol. 1997;89:501-506.

2. Moen MD. Surgery for urogenital prolapse. Rev Med Univ Navarra. 2004;48:50-55.

3. Lukacz ES, Lawrence JM, Contreras R, Nager CW, Luber KM. Parity, mode of delivery and pelvic floor disorders. $\mathrm{Ob}$ stet Gynecol. 2006;107:1253-1260.

4. Kim CM, Jeon MJ, Chung DJ, Kim SK, Kim JW, Bai SW. Risk factors for pelvic organ prolapse. Int $\mathrm{J}$ Gynaecol $\mathrm{Ob}$ stet. 2007;98:248-251.

5. Weber AM, Richter HE. Pelvic organ prolapse. Obstet Gynecol. 2005;106:615-634.

6. Vardy MD, Lindsay R, Scotti RJ et al. Short-term urogenital effects of raloxifene, tamoxifen and estrogen. Am J Obstet Gynecol. 2003;189:81-88.

7. Albertazzi P, Sharma S. Urogenital effects of selective estrogen receptor modulators: a systematic review. Climacteric. 2005;8:214-220.

8. Goldstein SR, Neven P, Zhour U, Taylor YU, Ciaccia AV, Plouffe Jr L. Raloxifene effects on frequency of surgery for pelvic floor relaxation. Obstet Gynecol. 2001;98:91-96.

9. Hendrix SL, McNeeley SG. Effect of selective estrogen receptor modulators on reproductive tissues other than endometrium. Ann NY Acad Sci. 2001;949:243-250.

10. Goldstein SR, Nanavati N. Adverse events that are associated with the selective estrogen receptor modulator levormeloxifene in an aborted phase 3 osteoporosis treatment study. Am J Obstet Gynecol. 2002;187:521-527.

11. Chomczynski P, Sacchi N. Single-step method of RNA isolation by acid guanidinium thiocyanate-phenol-chloroform extraction. Anal Biochem. 1987;162:156-159.

12. Jackson SR, Avery NC, Tarlton JP, Eckford SD, Abrams P, Bailey AJ. Changes in metabolism of collagen in genitourinary prolapse. Lancet. 1996;347:1658-1661.

13. Ewies AA, Elshafie M, Li J et al. Changes in transcription profile and cytoskeleton morphology in pelvic ligament fibroblasts in response to stretch: the effects of estradiol and levormeloxifene. Mol Hum Reprod. 2008;14:127-135.

14. Surazynski A, Jarzabek K, Haczynski J, Laudanski P, Palka J, Wolczynski S. Differential effects of estradiol and raloxifene on collagen biosynthesis in cultured human skin fibroblasts. Int J Mol Med. 2003;12:803-809.

15. Reay Jones NH, Healy JC, King LJ, Saini S, Shousha S, Allen-Mersh TG. Pelvic connective tissue resilience decreases with vaginal delivery, menopause and uterine prolapse. Br J Surg. 2003;90:466-472.

16. Slayden OD, Hettrich K, Carroll RS, Otto LN, Clark AL, Brenner RM. Estrogen enhances cystatin C expression in the macaque vagina. J Clin Endocrinol Metab. 2004;89:883-891.

17. Otto LN, Slayden OD, Clark AL, Brenner RM. The rhesus macaque as an animal model for pelvic organ prolapse. Am J Obstet Gynecol. 2002;186:416-421.

18. Rechberger T, Donica H, Baranowski W, Jakowicki J. Female urinary stress incontinence in terms of connective tissue biochemistry. Eur J Obstet Gynecol Reprod Biol. 1993;49:187-191.

19. Franz HB, Wendler D, Oettling G. Immunohistochemical assessment of steroid hormone receptors in tissues of the anal canal. Implications for anal incontinence? Acta Obstet Gynecol Scand. 1996;75:892-895.

20. Lang JH, Zhu L, Sun ZJ, Chen J. Estrogen levels and estrogen receptors in patients with stress urinary incontinence and pelvic organ prolapse. Int J Gynaecol Obstet. 2003;80:35-39.

21. Mokrzycki ML, Mittal K, Smilen SW, Blechman AN, Porges RF, Demopolous RI. Estrogen and progesterone receptors in the uterosacral ligament. Obstet Gynecol. 1997;90:402-404.

22. Ewies AA, Thompson J, Al-Azzawi F. Changes in gonadal steroid receptors in the cardinal ligaments of prolapsed uteri: immunohistomorphometric data. Hum Reprod. 2004;19: $1622-1628$.

23. Sharma S, Albertazzi P, Bottazzi M. The long-term effect of raloxifene on the genitourinary tract. Climacteric. 2007; 10:244-248.

24. Pal L, Hailpern SM, Santoro NF et al. Association of pelvic organ prolapse and fractures in postmenopausal women: analysis of baseline data from the Women's Health Initiative Estrogen Plus Progestin trial. Menopause. 2008;15:59-66.

25. Affinito P, Palomba S, Sorrentino C et al. Effects of postmenopausal hypoestrogenism on skin collagen. Maturitas. 1999;33:239-247.

26. Bailey AJ, Sims TJ, Ebbesen EN, Mansell JP, Thomsen JS, Mosekilde L. Age-related changes in the biochemical properties of human cancellous bone collagen: relationship to bone strength. Calcif Tissue Int. 1999;65:203-210.

27. Ettinger B, Black DM, Mitlak BH et al. Reduction of vertebral fracture risk in postmenopausal women with osteoporosis treated with raloxifene. Results from a 3-year randomized clinical trial. JAMA. 1999;282:637-645.

28. Delmas PD, Bjarnason NH, Mitlak BH et al. Effects of raloxifene on bone mineral density, serum cholesterol concentrations, and uterine endometrium in postmenopausal women. N Engl J Med. 1997;337:1641-1647.

Submitted: 2 March, 2011

Accepted after reviews: 27 June, 2011 